\title{
KAMILA MROZEK
}

ORCID: 0000-0001-7973-0281

Uniwersytet Wrocławski

\section{ZMIANA SPOSOBU WYKONYWANIA ZAKAZU PROWADZENIA POJAZDÓW W TRYBIE ART. 182A K.K.W.}

\begin{abstract}
Abstrakt: Niniejsza publikacja poświęcona jest instytucji przewidzianej w art. 182a k.k.w., to jest zakazowi prowadzenia pojazdów niewyposażonych w blokadę alkoholową. Celem omawianej konstrukcji prawnej jest zmiana sposobu wykonywania środka karnego w postaci zakazu prowadzenia pojazdów, uzależniona od warunków przewidzianych przez ustawodawcę w treści analizowanego przepisu. Oceny tytułowej instytucji dokonano na podstawie analizy podstaw o charakterze formalnoprawnym oraz materialnoprawnym. Wskazano też na kwestię zastosowania art. 182a k.k.w., gdy sprawca w czasie popełnienia przestępstwa był pod wpływem środka odurzającego lub zbiegł $\mathrm{z}$ miejsca zdarzenia.
\end{abstract}

Słowa kluczowe: zakaz prowadzenia pojazdów, blokada alkoholowa, środek karny, prognoza kryminologiczna

Prawo karne wykonawcze stanowi - obok prawa karnego materialnego i procesowego - samodzielną gałąź prawa, rządzącą się własnym katalogiem zasad, których zadaniem jest wskazanie podstawowych wartości, jakimi kierował się ustawodawca, przyjmując określone rozwiązania prawne. W katalogu tym wyróżnia się trzy kategorie zasad: zasady ogólne, zasady będące kontynuacją podstawowych zasad prawa karnego materialnego i procesu karnego w stadium wykonania orzeczenia oraz zasady swoiste dla tej dziedziny prawa ${ }^{1}$. W kontekście tematyki niniejszego opracowania szczególną rolę przypisać należy zasadzie elastycznej modyfikacji kar i innych środków reakcji na przestępstwo, skatalogowanej w ramach zasad swoistych dla prawa karnego wykonawczego.

W postępowaniu wykonawczym zasada ta tworzy obowiązek dopasowywania treści zastosowanej sankcji karnej do form i metod oddziaływania na skazanych, przekształcających się w miarę postępów w resocjalizacji. Postępowanie to

1 T. Kalisz, Zasady prawa karnego wykonawczego, „Nowa Kodyfikacja Prawa Karnego” 17, 2005, s. 316-317. 
bowiem cechuje się dynamiką, a zachodzące w trakcie wykonywania orzeczeń zmiany powinny znajdować odzwierciedlenie w treści wydawanych postanowień. W konsekwencji do filarów omawianej zasady należą zarówno rozwojowy charakter postępowania wykonawczego, jak i potrzeba okresowej oceny procesu wykonywania orzeczeń. Pamiętać jednak należy, że oceniane są nie tylko zachowania pozytywne, mogące prowadzić do złagodzenia, a nawet skrócenia stopnia dolegliwości sankcji karnej, lecz także zachowania negatywne, które powinny przynosić skutek zupełnie odwrotny. Zasadę elastycznej modyfikacji kar i innych środków prawnokarnej reakcji na przestępstwo kształtują zatem dwa zasadnicze pojęcia: progresja, czyli wywołanie u skazanego oczekiwanych zmian, oraz regresja, rozumiana jako pojawienie się niepokojących oznak pogłębiania się przyczyn wykolejenia społecznego ${ }^{2}$.

Ustawą z dnia 20 marca 2015 roku o zmianie ustawy — Kodeks karny oraz niektórych innych ustaw ${ }^{3}$ wprowadzono do prawa karnego wykonawczego nową, dotychczas nieznaną instytucję, polegającą na zmianie (skróceniu) sposobu wykonywania środka karnego w postaci zakazu prowadzenia pojazdów niewyposażonych w blokadę alkoholową.

Warto zauważyć, że początkowo ustawodawca miał zupełnie inny pomysł na wykorzystanie tak zwanych blokad alkoholowych. Projekt ustawy o zmianie ustawy - Kodeks karny oraz niektórych innych ustaw 4 przedstawiony w 2014 roku zakładał, że obowiązek prowadzenia pojazdu wyposażonego w blokadę alkoholową nakładany będzie na sprawcę, który po upływie okresu objętego zakazem prowadzenia pojazdów wystąpi z wnioskiem o przywrócenie utraconych uprawnień. Obowiązek ten miał być nakładany na okres trzech lat, a informacja o nim miała być odnotowywana w prawie jazdy w kategorii kodu.

Zaproponowane rozwiązanie odpowiadało ratio legis ówczesnej nowelizacji prawa karnego w zakresie, w jakim dotyczyła ona potrzeby bardziej zdecydowanego działania na rzecz poprawy bezpieczeństwa w ruchu drogowym, a zwłaszcza ograniczenia zjawiska prowadzenia pojazdów mechanicznych w stanie nietrzeźwości.

Już jednak na etapie prac legislacyjnych nad projektem zauważono, że konstrukcja ta może naruszać zasadę ne bis in idem. Zasada ta wyraża zakaz podwójnego karania tej samej osoby za popełnienie tego samego czynu zabronionego. Chodziło bowiem o to, że za ten sam czyn wobec sprawcy przestępstwa przeciwko bezpieczeństwu w komunikacji można było orzec karę i określony środek karny, a po ich wykonaniu — nałożyć dodatkowy obowiązek w postaci zakazu prowadzenia pojazdów niewyposażonych w blokadę alkoholową. W tym drugim

2 Ibidem.

3 Ustawa z dnia 20 marca 2015 roku o zmianie ustawy - Kodeks karny oraz niektórych innych ustaw (Dz.U. z 2015 r. poz. 541).

${ }^{4}$ Uzasadnienie do projektu Ustawy o zmianie ustawy — Kodeks karny oraz niektórych innych ustaw z dnia 13 czerwca 2014 roku, druk nr 2586 Sejmu VII kadencji. 
przypadku proponowano wykorzystanie reżimu administracyjnego, tak aby zatrzeć wrażenie wprowadzenia do systemu prawa karnego nowego środka karnego polegającego na zakazie prowadzenia pojazdów niewyposażonych w blokadę alkoholową. Rozwiązanie to przypominało w swojej konstrukcji swoisty środek represyjny stosowany $\mathrm{w}$ interesie ogólnym ${ }^{5}$. Stanowiło nadto wyraz nadmiernego rygoryzmu prawnego przy jednoczesnym braku poszanowania konstytucyjnej zasady proporcjonalności. Warto w tym miejscu dodać, że sankcją za naruszenie tego obowiązku miało być zatrzymanie prawa jazdy oraz cofnięcie uprawnień na okres 12 miesięcy.

Słusznie zwrócono uwagę na jeszcze jedną kwestię związaną z instytucją zatarcia skazania ${ }^{6}$. Wprowadzenie komentowanego rozwiązania w kształcie, jaki zakładał pierwotny projekt, to jest $\mathrm{w}$ formie trzyletniego obowiązku prowadzenia pojazdu wyposażonego w blokadę alkoholową, powodowałoby problemy z faktycznym zatarciem skazania. Nie zawsze bowiem sprawca automatycznie po wykonaniu środka karnego w postaci zakazu prowadzenia pojazdów występowałby o przywrócenie utraconych na skutek popełnionego czynu zabronionego uprawnień. Skorzystanie z tej możliwości kilka czy kilkanaście lat po upływie zakazu powodowałoby ten skutek, że przez cały ten czas wyrok skazujący nie mógłby ulec zatarciu. To z kolei wprowadzałoby niczym nieuzasadnioną nierównowagę pomiędzy skazanymi za prowadzenie pojazdów mechanicznych w stanie nietrzeźwości, warunkowaną decyzją o przystąpieniu do egzaminu i jego pozytywnym zakończeniu.

Konstrukcja z art. 182a k.k.w. zakłada możliwość zmiany sposobu wykonywania zakazu, o którym mowa w treści art. 42 k.k., w razie łącznego spełnienia przez skazanego dwóch warunków: o charakterze formalnoprawnym oraz o charakterze materialnoprawnym.

Ustawodawca wprowadził cenzus czasu. Złożenie przez skazanego wniosku w trybie art. 182a k.k.w. możliwe jest wyłącznie, gdy środek karny w postaci zakazu prowadzenia pojazdów wykonywany był przez co najmniej połowę orzeczonego wymiaru. Zasada ta z przyczyn oczywistych nie ma zastosowania w przypadku skazanych, wobec których sąd orzekł zakaz prowadzenia wszelkich pojazdów mechanicznych dożywotnio - wówczas złagodzenie represyjności środka karnego, o którym mowa w art. 42 § 3 i 4 k.k., możliwe jest dopiero po upływie co najmniej dziesięcioletniego okresu jego wykonywania?

5 A. Sakowicz, Opinia prawna na temat ustawy o zmianie ustawy - Kodeks karny oraz niektórych innych ustaw (druk sejmowy 2586), s. 10.

${ }^{6}$ Uzasadnienie..., s. 7.

${ }^{7}$ Na marginesie warto wspomnieć, że początkowo - jeszcze na etapie prac Komisji Nadzwyczajnej do spraw zmian w kodyfikacjach — zakładano wprowadzenie dodatkowego ograniczenia czasowego. Rozważano bowiem możliwość stosowania tego rozwiązania po odbyciu co najmniej połowy orzeczonego wymiaru, nie wcześniej jednak niż po upływie 18 miesięcy, to jest połowy okresu, o którym mowa w art. $42 \S 3$ k.k. Przepis ten miał mieć zastosowanie wyłącznie do spraw- 
Zastanawiać może, czy chociażby w kontekście powyższego ograniczenia instytucja $z$ art. 182a k.k.w. ma zastosowanie, gdy sąd na podstawie art. 67 § 3 k.k. warunkowo umorzy postępowanie karne, orzekając jednocześnie środek karny w postaci zakazu prowadzenia pojazdów wymieniony w art. 39 pkt 3 k.k. Wyjaśnić należy, że w przypadku skorzystania przez sąd z przedmiotowego środka probacyjnego okres, na jaki można orzec zakaz prowadzenia pojazdów, jest znacznie krótszy - wynosi bowiem maksymalnie dwa lata. Jako że środki karne orzeka się w latach, wymiar tego środka może wynosić wyłącznie albo rok, albo dwa lata ${ }^{8}$. Oznacza to, że we wspomnianym przypadku zmiana sposobu wykonywania zakazu prowadzenia pojazdów teoretycznie możliwa byłaby już po upływie sześciu miesięcy od daty rozpoczęcia realizacji przedmiotowego środka karnego. $\mathrm{Z}$ treści art. 182a k.k.w. nie wynika, aby ustawodawca wykluczył z kręgu osób uprawnionych do skorzystania $\mathrm{z}$ dobrodziejstwa wspomnianego przepisu sprawców, wobec których sąd zastosował warunkowe umorzenie postępowania karnego, skutkujące orzeczeniem zakazu na okres krótszy niż trzy lata. Jeśli więc zakaz był wykonywany przez okres co najmniej połowy orzeczonego wymiaru, czyli sześciu miesięcy lub roku, a postawa, właściwości i warunki osobiste sprawcy oraz zachowanie $\mathrm{w}$ okresie wykonywania środka uzasadniają przekonanie, że prowadzenie pojazdu przez tę osobę nie zagraża bezpieczeństwu w komunikacji, nic nie stoi na przeszkodzie, aby sąd wydał postanowienie, o którym mowa w art. 182a k.k.w. Ograniczenie, o którym mowa w treści art. 6 ustawy nowelizującej, dotyczy wyłącznie osób, w stosunku do których przed dniem 19 kwietnia 2015 roku orzeczono prawomocnym wyrokiem środek karny zakazu prowadzenia pojazdów na podstawie art. $42 \S 2$ k.k., i jest związane z podniesieniem w 2015 roku dolnej granicy stosowania tego środka do lat trzech. Także możliwość wykorzystania tytułowej instytucji wobec wszystkich odmian zakazu prowadzenia pojazdów, to jest na podstawie art. 42 § 1, 2, 3 i 4 k.k., potwierdza słuszność zajętego stanowiska9

Stefan Lelental wskazuje nadto na dodatkową podstawę formalnoprawną skrócenia wykonywania zakazu prowadzenia pojazdów, to jest na wyposażenie pojazdu w blokadę alkoholową ${ }^{10}$.

ców, w stosunku do których orzeczono zakaz prowadzenia pojazdów na okres nie krótszy niż trzy lata. Ostatecznie propozycja ta znalazła się w art. 6 ustawy nowelizującej i została ograniczona do osób, w stosunku do których przed dniem wejścia w życie tejże ustawy orzeczono prawomocnym wyrokiem środek karny w postaci zakazu prowadzenia pojazdów na podstawie art. $42 \S 2$ ustawy z dnia 6 czerwca 1997 roku — Kodeks karny (Dz.U. z 1997 r. Nr 88, poz. 553, ze zm.).

8 V. Konarska-Wrzosek, [w:] Kodeks karny. Komentarz, red. Violetta Konarska-Wrzosek, Warszawa 2018, s. 436.

9 Teza ta zostanie rozwinięta poniżej.

10 Blokada alkoholowa w rozumieniu art. 2 pkt 84 ustawy z dnia 20 czerwca 1997 roku Prawo o ruchu drogowym (Dz.U. z 2012 poz. 1137 ze zm.) to urządzenie techniczne uniemożliwiające uruchomienie silnika pojazdu silnikowego i pojazdu szynowego w przypadku, gdy zawartość alkoholu w wydychanym przez kierującego powietrzu wynosi co najmniej $0,1 \mathrm{mg}$ alkoholu w $1 \mathrm{dm}^{3}$; zob. S. Lelental, Kodeks karny wykonawczy. Komentarz, Warszawa 2017, s. 749. 
Podstawę materialnoprawną z kolei tworzą: postawa sprawcy, jego właściwości i warunki osobiste oraz zachowanie w trakcie wykonywania środka karnego. Suma tych okoliczności, tworząca prognozę kryminologiczną, powinna uzasadniać przekonanie, że prowadzenie pojazdu przez tę osobę nie zagraża bezpieczeństwu w komunikacji11.

Oceniając postawę sprawcy, sąd będzie brał pod uwagę w szczególności postawę po popełnieniu przestępstwa, a zwłaszcza różne formy zachowania i zadośćuczynienia wobec pokrzywdzonego, starania o naprawienie szkody, wyrażoną skruchę czy bezzwłoczne poddanie się wszystkim rygorom wynikającym z wyroku. Do okoliczności definiujących właściwości i warunki osobiste sprawcy należą z kolei: stan zdrowia, cechy osobowości i charakteru, utrwalone sposoby reagowania na stres i sytuacje trudne, stabilizacja trybu życia, warunki rodzinne i środowiskowe oraz stabilność społecznie pożądanych postaw. Także zachowanie skazanego w okresie wykonywania środka karnego w postaci zakazu prowadzenia pojazdów, rozumiane jako przestrzeganie porządku prawnego, utrzymywanie abstynencji od alkoholu czy unikanie środowisk patologicznych, będzie decydowało o możliwości zastosowania dobrodziejstwa $\mathrm{z}$ art. 182a k.k.w. ${ }^{12}$

Zebranie wskazanych informacji następuje w trybie określonym w art. 14 k.k.w. w drodze wywiadu środowiskowego, przeprowadzonego przez sądowego kuratora zawodowego na polecenie sądu, który rozpoznaje wniosek w trybie art. 182a k.k.w. Ważne też w kontekście przedmiotowego postępowania są informacje o skazanym, jakimi dysponuje policja.

Sąd, który wydał orzeczenie w pierwszej instancji — zgodnie z zasadą wyrażoną $\mathrm{w}$ art. $3 \S 1$ k.k.w., rozpoznaje wniosek o dalsze wykonywanie środka karnego w postaci zakazu prowadzenia pojazdów niewyposażonych w blokadę alkoholową. Decyzja sądu zawsze ma charakter fakultatywny, co wynika bezpośrednio z brzmienia art. 182a $§ 1$ k.k.w. Nawet jeśli wszystkie okoliczności, czy to związane z postawą, czy właściwościami i warunkami osobistymi sprawcy oraz zachowaniem w trakcie wykonywania środka karnego, świadczą o pozytywnej prognozie kryminologicznej, sąd może nie uwzględnić wniosku, powołując się na przykład na charakter czynu bądź jego negatywny odbiór społeczny ${ }^{13}$.

Legitymacja do złożenia przedmiotowego wniosku przysługuje skazanemu, jego obrońcy oraz prokuratorowi. Sąd może zainicjować takie postępowanie również z urzędu. Odpowiednie stosowanie art. 182 k.k.w. oznacza obowiązek

11 Pojęcie bezpieczeństwa w komunikacji jest węższe niż pojęcie bezpieczeństwa powszechnego. „Komunikacja” natomiast oznacza transport, przemieszczanie się na takich obszarach ruchu lądowego, powietrznego oraz wodnego, do których dostęp ma bliżej nieokreślony krąg podmiotów. Komunikacja nie odbywa się natomiast w miejscach, które nie są powszechnie uczęszczane przez ludzi na przykład na łąkach, w lasach. Zob. J. Lachowski, [w:] Kodeks karny. Komentarz, red. Violetta Konarska-Wrzosek, Warszawa 2018, s. 855.

12 K. Postulski, Kodeks karny wykonawczy. Komentarz, Warszawa 2017, s. 884.

13 Ibidem. 
przesłania postanowienia w przedmiocie dalszego wykonywania środka karnego, o którym mowa w art. 42 k.k., w postaci zakazu prowadzenia pojazdów niewyposażonych w blokadę alkoholową odpowiednim organom administracji rządowej lub samorządu terytorialnego właściwym odnośnie do miejsca zamieszkania skazanego. Obowiązek ten spoczywa na sądzie, który wydał postanowienie w trybie art. 182a k.k.w. Dodatkowo - jeżeli skazany prowadził pojazd, wykonując pracę zarobkową - o orzeczeniu tym sąd zawiadamia pracodawcę, u którego skazany jest zatrudniony.

Należałoby zastanowić się nad jeszcze jedną kwestią — czy instytucja $\mathrm{z}$ art. 182a k.k.w. ma zastosowanie w wypadku orzeczenia zakazu prowadzenia pojazdów na podstawie art. $42 \S 1$ lub 1a k.k. czy też art. $42 \S 2-4$ k.k., gdy sprawca $\mathrm{w}$ czasie popełnienia jednego z przestępstw tam wymienionych był pod wpływem środka odurzającego lub zbiegł z miejsca zdarzenia. Skoro bowiem mówimy o obowiązku wyposażenia pojazdu w blokadę alkoholową, to mogłoby się wydawać, że konstrukcja ta przeznaczona jest wyłącznie dla sprawców przestępstw przeciwko bezpieczeństwu w komunikacji, tylko gdy popełnili je w stanie nietrzeźwości. Tymczasem ograniczenie takie nie wynika wprost z treści art. 182a k.k.w. Analizowany przepis operuje określeniem ogólnym w postaci środka karnego zakazu prowadzenia pojazdów. Wątpliwości wynikać mogą z wprowadzenia przez ustawodawcę zastrzeżenia, mówiącego że jeśli zakaz prowadzenia pojazdów - a więc także ten orzeczony na podstawie art. $42 \S 1-2$ k.k. - był wykonywany przez okres co najmniej połowy orzeczonego wymiaru, sąd może orzec o dalszym wykonywaniu tego środka karnego w postaci zakazu prowadzenia pojazdów niewyposażonych w blokadę alkoholową. W razie natomiast orzeczenia zakazu na podstawie art. $42 \S 3$ lub 4 k.k. warunek temporalny zostanie spełniony po upływie co najmniej dziesięciu lat od daty rozpoczęcia wykonywania tego środka. Oznacza to więc, że instytucja z art. 182a k.k.w. może być stosowana w wypadku orzeczenia zakazu prowadzenia pojazdów orzekanego zarówno fakultatywnie na podstawie art. $42 \S 1$ k.k., obligatoryjnie na podstawie art. 42 $\S 1$ la lub 2 k.k., jak i obligatoryjnie na zasadzie art. $42 \S 3$ lub 4 k.k. Należy przy tym pamiętać, że zakaz, o którym mowa w treści art. $42 \S 1$ i 1a k.k., może być orzeczony od roku do lat 15.

Warto podkreślić, że możliwości tej nie odrzucał również ustawodawca, który jeszcze na etapie prac legislacyjnych nad projektem ustawy z dnia 20 marca 2015 roku wyraźnie wskazał, że

jeśli ktoś wykazał się taką niefrasobliwością, że złamał przepisy, sąd może dojść do wniosku, że rzeczywiste przyczyny złamania przepisów leżą znacznie głębiej i są połączone właśnie np. z chorobą alkoholową czy z uzależnieniem danego sprawcyod emocji. Przepis poszerza tak naprawdę paletę możliwości reakcji dla sądu, a jednocześnie nie wprowadza dyferencjacji pomiędzy sprawcami i nie ogranicza możliwości de facto złagodzenia środka tylko do pewnych grup osób skazanych ${ }^{14}$.

14 Pełny zapis przebiegu posiedzenia Komisji Nadzwyczajnej do spraw zmian w kodyfikacjach (nr 84) z dnia 15 stycznia 2015 roku, http://www.sejm.gov.pl/Sejm7.nsf/biuletyn.xsp?skrn$\mathrm{r}=\mathrm{NKK}-84$ (dostęp: 10.12.2020).

Przegląd Prawa i Administracji 124, 2021

(C) for this edition by CNS 
Także S. Lelental twierdzi, iż rozwiązanie zawarte w art. 182a $§ 1$ k.k.w. odnosi się do każdego środka karnego zakazu prowadzenia pojazdów, bez względu na materialnoprawną podstawę jego orzeczenia ${ }^{15}$.

Ustawodawca wprowadził również możliwość uchylenia sposobu wykonywania zakazu prowadzenia pojazdów w postaci, o której mowa w art. 182a $\S 1$ k.k.w. Podstawą uchylenia jest rażące naruszenie porządku prawnego w zakresie dotyczącym bezpieczeństwa ruchu drogowego, w szczególności popełnienie przestępstwa przeciwko bezpieczeństwu w komunikacji — i to niezależnie od strony podmiotowej czynu. Użycie określonego sformułowania „W szczególności” powoduje ten skutek, że z katalogu naruszeń skutkujących uchyleniem rozwiązania $\mathrm{z}$ art.182a k.k.w. nie można wykluczyć również czynów z rozdziału XI kodeksu wykroczeń, to jest czynów przeciwko bezpieczeństwu i porządkowi w komunikacji ${ }^{16}$.

Ustawodawca wyraźnie akcentuje ponadto, że nie każde naruszenie porządku prawnego stwarza możliwość uchylenia postanowienia, a tylko takie, które cechuje się wysokim stopniem pejoratywności. Chodzi zatem o naruszenia porządku prawnego charakteryzujące się jaskrawością, oczywistością, dużym nasileniem złej woli, przy jednoczesnym uwzględnieniu skutków, sposobu i okoliczności tego zachowania, stopnia jego społecznej szkodliwości czy rodzaju i wymiaru orzeczonej kary ${ }^{17}$.

Instytucją konkurencyjną do „zakazu”, o którym mowa w treści art. 182a k.k.w., jest mechanizm przewidziany w art. 84 k.k., przewidujący możliwość skrócenia okresu wykonywania środków karnych. Analiza powołanego przepisu pod kątem możliwości zastosowania go względem środka karnego w postaci zakazu prowadzenia pojazdów pozwala przyjąć, że najszersze zastosowanie będzie on miał w sytuacji, o której mowa w art. $42 \S 1$ i 1a k.k. ${ }^{18}$, z uwagi na wykluczenie jego stosowania wobec sprawców, którzy w czasie popełnienia przestępstwa byli w stanie nietrzeźwości, pod wpływem środka odurzającego lub zbiegli z miejsca zdarzenia (art. $42 \S 2$ k.k.). W tym przypadku konieczne jest, aby sprawca przestrzegał porządku prawnego, a środek karny był w stosunku do niego wykonywany przynajmniej przez rok. Co więcej, ustawodawca wprowadza możliwość

15 S. Lelental, op. cit., s. 748. Por. także K. Dąbkiewicz, Kodeks karny wykonawczy. Komentarz, Warszawa 2015, s. 745.

16 Ustawa z dnia 20 maja 1971 roku — Kodeks wykroczeń (Dz.U. z 1971 r. Nr 12, poz. 114).

17 S. Strycharz, Pojęcie porzadku prawnego w kodeksie karnym, „Nowe Prawo” 1970, nr 6, poz. 856 , s. $851-856$.

18 Art. $42 \S 1$ k.k. stanowi, że sąd może orzec zakaz prowadzenia pojazdów określonego rodzaju w razie skazania osoby uczestniczącej w ruchu za przestępstwo przeciwko bezpieczeństwu w komunikacji, w szczególności jeżeli z okoliczności popełnionego przestępstwa wynika, że prowadzenie pojazdu przez tę osobę zagraża bezpieczeństwu w komunikacji. Natomiast w myśl art. 42 $\S 1$ 1a k.k. sąd orzeka zakaz prowadzenia wszelkich pojazdów mechanicznych w razie skazania za przestępstwo określone w art. 178b lub 180a k.k., art., 244 k.k., jeżeli czyn sprawcy polegał na niezastosowaniu się do zakazu prowadzenia pojazdów mechanicznych. Ustawa z dnia 6 czerwca 1997 r. — Kodeks karny (Dz.U. z 1997 r. Nr 88, poz. 553).

Przegląd Prawa i Administracji 124, 2021

(C) for this edition by CNS 
skrócenia okresu wykonywania środka karnego w postaci zakazu prowadzenia pojazdów orzeczonego dożywotnio, pod warunkiem że skazany przestrzegał porządku prawnego i nie zachodzi obawa ponownego popełnienia przestępstwa podobnego do tego, za które orzeczono środek karny, a środek ten był w stosunku do skazanego wykonywany przynajmniej przez 15 lat. Co ważne, w doktrynie przyjmuje się, że możliwe jest nadto wcześniejsze uznanie za wykonany zakazu prowadzenia pojazdów orzeczonego przy warunkowym umorzeniu postępowania karnego, jeżeli był on orzeczony na okres dwóch lat, zwłaszcza gdy okres ten wykraczał poza okres próby ${ }^{19}$.

Wprowadzenie przez ustawodawcę do porządku krajowego możliwości zmiany sposobu wykonywania zakazu prowadzenia pojazdów w trybie art. 182a k.k.w. należy ocenić pozytywnie. Po pierwsze, instytucja ta - mimo wprowadzenia w 2015 roku restrykcyjnych zasad karania sprawców popełniających przestępstwa przeciwko bezpieczeństwu w komunikacji w stanie nietrzeźwości lub pod wpływem środka odurzającego - stanowi przejaw pewnego liberalizmu ustawodawcy. W wyjątkowych przypadkach dopuszcza on bowiem - przy spełnieniu warunków określonych w treści art. 182a k.k.w. — złagodzenie formy wykonywania środka karnego w postaci zakazu prowadzenia pojazdów. Po drugie zaś, instytucja ta daje sprawcom incydentalnym, to jest przypadkowym, szansę szybszego powrotu do normalnego funkcjonowania, przy jednoczesnym zachowaniu funkcji prewencyjnej przedmiotowego środka karnego, przejawiającej się w zapobieżeniu popełnieniu ponownego przestępstwa chociażby na skutek wyposażenia pojazdu mechanicznego w blokadę uniemożliwiającą uruchomienie silnika pojazdu, w przypadku gdy zawartość alkoholu w wydychanym przez kierującego powietrzu wynosi co najmniej $0,1 \mathrm{mg} / 1 \mathrm{dm}^{3}$. Probacyjny charakter tego rozwiązania, którego odzwierciedleniem jest fakultatywna możliwość uchylenia stosowania sposobu wykonywania zakazu prowadzenia pojazdów w postaci, o której mowa $\mathrm{w}$ art. 182a $\S 1$ k.k.w., daje natomiast skazanemu motywację do sumiennego przestrzegania zasad wynikających z decyzji sądu.

\section{CHANGE IN THE MANNER OF EXECUTING \\ A DRIVING BAN PURSUANT TO ART. 182A OF THE POLISH EXECUTIVE PENAL CODE}

\section{Summary}

This publication is devoted to the institution provided for in article 182a of the Polish Executive Penal Code, i.e., a ban on driving vehicles not equipped with an alcohol interlock. The aim of the discussed legal structure is to change the manner of executing a criminal measure in the

19 V. Konarska-Wrzosek, [w:] Kodeks karny. Komentarz, red. V. Konarska-Wrzosek, Warszawa 2018, s. 494. 
form of a driving ban, depending on the conditions provided for by the legislator in the content of the analyzed provision. The assessment of the institution was based on the analysis of formal and substantive grounds. The attention was also paid to the problem of the applicability of article 182a of the Code of Criminal Procedure in a situation where the perpetrator was under the influence of a narcotic drug or fled the scene at the time of committing the crime.

Keywords: driving ban, alcohol interlock, punitive measure, criminological forecast

\section{BIBLIOGRAFIA}

\section{LITERATURA}

Dąbkiewicz K., Kodeks karny wykonawczy. Komentarz, Warszawa 2015.

Kalisz T., Zasady prawa karnego wykonawczego, „Nowa Kodyfikacja Prawa Karnego” 17, 2005.

Konarska-Wrzosek V., [w:] Kodeks karny. Komentarz, red. Violetta Konarska-Wrzosek, Warszawa 2018.

Lachowski J., [w:] Kodeks karny. Komentarz, red. Violetta Konarska-Wrzosek, Warszawa 2018.

Lelental S., Kodeks karny wykonawczy. Komentarz, Warszawa 2017.

Postulski K., Kodeks karny wykonawczy. Komentarz, Warszawa 2017.

Sakowicz A., Opinia prawna na temat ustawy o zmianie ustawy - Kodeks karny oraz niektórych innych ustaw, druk nr 2586 Sejmu VII kadencji.

Strycharz S., Pojęcie porzadku prawnego w kodeksie karnym, „Nowe Prawo” 1970, nr 6, poz. 856.

Uzasadnienie do projektu ustawy o zmianie ustawy — Kodeks karny oraz niektórych innych ustaw z dnia 13 czerwca 2014 roku, druk nr 2586 Sejmu VII kadencji.

\section{AKTY PRAWNE}

Ustawa z dnia 20 maja 1971 roku — Kodeks wykroczeń (Dz.U. z 1971 r. Nr 12, poz. 114).

Ustawa z dnia 6 czerwca 1997 roku — Kodeks karny (Dz.U. z 1997 r. Nr 88, poz. 553 ze zm).

Ustawa z dnia 20 czerwca 1997 roku — Prawo o ruchu drogowym (Dz.U. z 2012 r. poz. 1137 ze zm.).

Ustawa z dnia 20 marca 2015 roku o zmianie ustawy — Kodeks karny oraz niektórych innych ustaw (Dz.U. z 2015 r. poz. 541).

\section{INNE}

Pełny zapis przebiegu posiedzenia Komisji Nadzwyczajnej do spraw zmian w kodyfikacjach (nr 84) z dnia 15 stycznia 2015 roku http://www.sejm.gov.pl/Sejm7.nsf/biuletyn.xsp?skrnr=NKK-84 (dostęp: 10.12.2020). 
Przegląd Prawa i Administracji 124, 2021

(C) for this edition by CNS 